\title{
Portret Herodota w traktacie De Herodoti malignitate Plutarcha z Cheronei
}

\author{
Anna MARCHEWKA*
}

\begin{abstract}
Portrait of Herodotus in the light of Plutarch's treatise De Herodoti malignitate: As a Platonist and moralist Plutarch paid particular attention truth. No wonder that in his reference to Herodotus' Histories he took into consideration the issue of historical truth, which was for him very important - both in its ethical as well as didactic aspect. In his De Herodoti malignitate the Chaeronean moralist is concerned with truth as well as with offering moral uplift. Plutarch presents Herodotus as a perfidious liar who falsely presented such famous and heroic Greeks as Miltiades, Leonidas, Themistocles or Pausanias and - above all - depreciatingly treated the Boeotians and Corinthians. Moreover, Plutarch accuses the historian of Halicarnassus of being

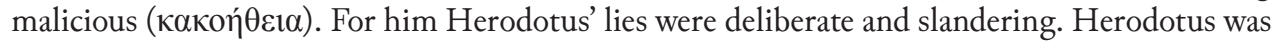
also a blasphemer, a pro-barbarian historian; a man who disregarded women. Finally, we get

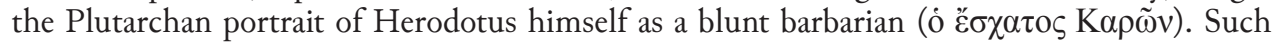
a presentation of Herodotus seems to attest to Plutarch's own prejudices, if not wickedness. By the same, however, one must take into consideration the literary tradition in which the whole treatise is rooted. So De Herodoti malignitate contains features of historical polemics and is an example of judicial rhetoric, in which the biographer attempts at persuading his readers that his charges against Herodotus are well justified. The treatise is a work representing the new intellectual trend, the so-called Second Sophistic; a polemic written in a period when the Greek intellectuals were deeply engaged in taking issues with past writers. Moreover, a fundamental aspect of De Herodoti malignitate should be taken into account - truth which is analyzed from a moral and psychological perspective. Although a leading motif of the treatise is truthfulness, the direct subject-matter of Plutarch's considerations remains a lie, or - to put it exactly lying. Accordingly, the Boeotian moralist singles out and analyses all the fundamental forms of lying. A suitable interpretation of the treatise De Herodoti malignitate depends thus on our
\end{abstract}

* Dr hab., prof. UG, Katedra Filologii Klasycznej Uniwersytetu Gdańskiego. E-mail: anna. marchewka@ug.edu.pl. 
knowledge of the cultural distance between Herodotus and Plutarch, although both authors were the representatives of Greek prosa.

\section{KEYWORDS}

Plutarch; Herodotus; truth; liar; malice; moralist

Herodot swoje Dzieje (Historiae) skończył pisać w latach dwudziestych V wieku. Na ten sam okres, czyli w przybliżeniu na rok 425 przed Chr., powszechnie jest datowana jego śmierć 1 . Pięćset lat później ów wybitny Halikarnasyjczyk, przez Cycerona nazwany „ojcem historii”, stał się tematem dociekań literackich Plutarcha, a dokładniej traktatu krytyczno-literackiego, jak go określa Tadeusz

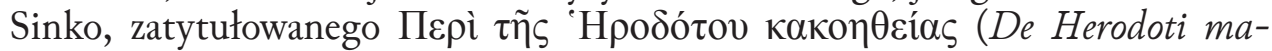
lignitate). Konrad Ziegler grupę pism, do których zaliczamy interesujący nas traktat, nazwał pismami literacko-historyczno-egzegetycznymi („die literarhistorisch-exegetischen Schriften") (Ziegler, 1951: 871n.).

Zanim jednak bliżej przyjrzymy się wizerunkowi Herodota u Plutarcha, przypomnijmy sobie pokrótce, jak nasz historyk był postrzegany i oceniany w wiekach wcześniejszych. Herodot był tego rodzaju twórcą, którego siła oddziaływania przez całą starożytność była niezmienna. Różnicę stanowi tylko zakres i forma wpływu jego dzieła — od zwykłego zachwytu nad językiem i stylem po krytykę jako źródła etnograficzno-geograficznego i historycznego. Sofokles, z którym Herodota łączyła przyjaźń, miał od historyka zapożyczyć motyw Antygony-siostry ${ }^{2}$. Fakt, że Halikarnasyjczyk przez starożytnych był postrzegany bądź to jako historyk, bądź to jako logograf, miał istotny wpływ na rozwój greckiej historiografii. Przy czym im większy dystans czasowy dzielit późniejszych historiografów antycznych od twórcy Dziejów, tym bardziej i tym częściej był on wykorzystywany jako źródło wiedzy etnograficzno-geograficznej i historycznej. Dzieło Herodota miało z pewnością ważny wpływ już na Tukidydesa. Simon Hornblower twierdzi nawet, że ów wpływ był „głęboki i przenikający" (profound and pervasive) (Hornblower, 2006: 308). Mowa tu, oczywiście, o wpływie antytetycznym, polegającym na odrzuceniu. Tym, co zarówno łączy, jak i różni obu historyków, jest podejście do prawdy.

Pierwszym twórcą, który podjął otwarty dialog, a właściwie ostrą polemikę z Herodotem, był Ktezjasz z Knidos. Uważany za epigona historiografii

${ }^{1}$ Zdaniem niektórych uczonych należy przesunąć datę publikacji Dziejów o około dziesięć lat, z czym wiąże się przypuszczenie, że Herodot mógł żyć dłużej, niż powszechnie się przyjmuje. Charles W. Fornara w oparciu o analizę Herodotowych inspiracji i motywów, jakie wykazują tragedie Eurypidesa, uznał, że sztuki z ostatnich siedmiu lub sześciu lat życia poety powstały pod wyraźnym wpływem dzieła historyka (Fornara, 1971: 25-34; por. Hornblower, 2006: 307).

${ }^{2}$ Zdaniem Stephanie West za Herodotowy należy uznać motyw brata, ale również wizerunek Sofoklesowego Kreona, który wykazuje pewne wspólne rysy z takimi władcami ukazanymi w Dziejach, jak Kambizes, Periander czy Polikrates (West, 1999: 131). 
jońskiej Knidyjczyk odnosił się do Halikarnasyjczyka z lekceważeniem czy wręcz pogardą. Dowodem na to jest następujące stwierdzenie Focjusza, który w połowie IX wieku dokonał wyciągu z Persiká: „Przeczytałem dzieło Ktezjasza z Knidos Persiká w XXIII księgach [...]. Prawie we wszystkich tych księgach podaje nie tylko rzeczy sprzeczne z Herodotem, lecz nazywa go także wielokrotnie kłamcą i bajarzem" (Bibliotheca 72, Persica 1; przekł. K. Głombiowski). W tym samym okresie, czyli w wieku IV przed Chr., spoglądano na Herodota również łaskawszym okiem. Wystarczy wymienić Eforosa z Kyme czy Theopompa z Chios.

Herodotowe Dzieje nowego znaczenia nabrały po podbojach Aleksandra Wielkiego. Tym, którzy pragnęli poznać i nazwać nowe terytoria oraz zjawiska kulturowe, zaoferowaty pewien mechanizm interpretacji. Nagminnie pojawia się stary poczwórny schemat etnograficzny: geografia - zwyczaje - cuda historia polityczna (Hornblower, 2006: 312). Pod wpływem Herodota znajdowała się zatem historiografia jońska, reprezentowana przez Hekatajosa z Abdery, Megasthenesa, Berossosa czy Manethona.

U progu okresu rzymskiego, czyli w czasach Dionizjusza z Halikarnasu i Liwiusza, Herodot był już klasykiem, z którym polemizowano i którego można było swobodnie adaptować. Niezależność wobec twórcy Dziejów wyrażano zazwyczaj poprzez uznanie go za głupca i kłamcę (Hornblower, 2006: 315). Herodotowe dzieło miało szczególne znaczenie w pierwszych trzech stuleciach po Chrystusie. Jedną z ważnych przyczyn takiej atencji względem greckiego historyka były wieloletnie zmagania Rzymu z Partami, w których to postrzegano nowych Persów ${ }^{3}$. Dzieje nadal bowiem pozostają ważnym źródłem ówczesnej wiedzy o wojnach grecko-perskich. Herodot musiał zatem zajmować ważne miejsce $\mathrm{w}$ procesie dydaktycznym. $\mathrm{Z}$ drugiej jednak strony nie szczędzono mu, jak już wyżej zaznaczyłam, ostrych słów krytyki. Plutarch nie był w tym względzie odosobniony, chociaż jego atak na „ojca historii” nie wywarł, jak twierdzi Stanisław Witkowski, dużego wrażenia (Witkowski, 1925: 175). Około sto lat po Plutarchu swoją dezaprobatę względem Herodota wyraził Aelius Harpokra-

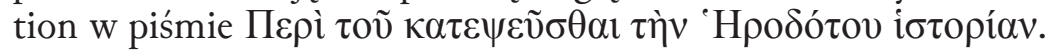

Wróćmy jednak do Plutarcha i jego traktatu. Doskonale nam wiadomo, że Dzieje nie są wyłącznie dziełem gloryfikującym waleczność i osiągnięcia Greków, zjednoczonych wobec zagrożenia ze strony „barbarzyńcy”. Podobnie jak władcy orientalni zostali ukazani nie tylko ze złej strony, czyli jako ludzie pyszni, okrutni i szaleni, ale również jako dobrzy i przemyślni władcy, tak również Greków mamy możliwość obserwować nie tylko jako mężów zacnych

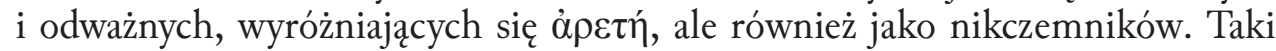
sposób przedstawienia przez Herodota swych bohaterów nie znalazł uznania

${ }^{3}$ Dla przykładu wystarczy wspomnieć częste odniesienia do Partów/Medów/Persów w poezji Horacego (np. Carm. I 2, 22; 2; 51; 27, 5; II 1, 31; 16, 6; III 8, 19; Carm. saec. v. 54). 
u Cheronejczyka, który z jednej strony był chwalcą rzymskiej potęgi i pax Romana, a z drugiej greckim patriotą, który jedynego ratunku dla Hellady upatrywał w jej moralnym i religijnym odrodzeniu. Cała bowiem jego działalność pro publico bono, czyli też urzędnicza, religijna i dydaktyczna, ukierunkowana była na urzeczywistnianie tych przekonań. Wytyczonym sobie zadaniom usiłował sprostać między innymi poprzez pracę literacką, która pozostawała w ścisłym związku z jego aktywnością dydaktyczną; niektóre wykłady wygłoszone w Akademii, zorganizowanej przez Plutarcha dla młodzieży z Beocji i jej okolicy, opracował literacko i wydał. Oczywiste jest, że wyznaczonym celom pedagogicznym musiał odpowiadać stosowny kanon lektur, będący nośnikiem oczekiwanych treści etycznych i religijnych. Dzieło Herodota oczekiwań tych, zdaniem naszego moralisty, nie spełniało.

Godna pochwały bezstronność twórcy Dziejów, który, jak podkreślił Witkowski, „ustrzegł się przeceniania zasług Greków, a obniżania czynów Persów” (Witkowski, 1925: 143), stała się przyczyną głębokiej do niego niechęci Cheronejczyka, wiedzionego silnym uczuciem lokalnego patriotyzmu. Już na samym początku De Herodoti malignitate czyni on historykowi zarzuty, że jednym najhaniebniej schlebia, a innych oczernia (855a). Do grona tych najbardziej skrzywdzonych zaliczył Plutarch naturalnie Beotów i Koryntian; przy czym największe jego oburzenie wywołało uznanie Tebańczyków za zdrajców, którzy sprzymierzyli się z Kserksesem. Niechęć zatem Herodota wobec Teb i Koryntu wywołuje zdecydowaną reakcję Plutarcha, którego romantyczne spojrzenie na grecką przeszłość skłoniło nie tylko do obrony swych przodków, ale prawdy historycznej w ogóle.

Patriotyzm wpłynął też na sposób, w jaki odniósł się do Herodota wspomniany już Ktezjasz z Knidos. Otóż mieszkańcy Halikarnasu i Knidos, dwóch miast położonych na przeciwległych brzegach zatoki Keramiakos, od wieków pałali do siebie nienawiścią. Fakt ów nie mógł pozostać bez wpływu na grecką historiografię. Ponadto Ktezjaszem, który urodził się i wychował w środowisku sympatyzującym ze Spartą, wyraźnie powodowały sympatie polityczne. Herodotowe Dzieje są, jak wiadomo, dziełem proateńskim. Jednakże o ile dla Ktezjasza Halikarnasyjczyk był zwykłym „kłamcą i bajarzem”, o tyle dla Plutarcha stał się przedmiotem poważnych rozważań etyczno-psychologicznych.

Cheronejczyk w oparciu o gęsto, jego zdaniem, rozsiane w Dziejach przejawy stronniczości i kłamliwości postawę historyka z Halikarnasu określił poję-

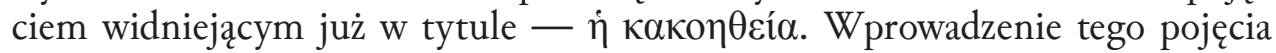
do tytułu wyraźnie sugeruje, że autor traktatu postanowił unaocznić odbiorcy ten właściwy, odarty z iluzji epickiej, charakter Herodota. Jako wielbiciel Platona Plutarch wierzył, że każde dzieło przenika charakterem autora (Lachenaud, 1981: 126n). Jesteśmy zatem z góry przygotowani na krytyczną ocenę „ojca historii”. I rzeczywiście, po zapoznaniu się z treścią De Herodoti malignitate skwapliwie przychylamy się do opinii Tadeusza Sinki, że mamy tu do czynienia 
z pamfletem (Sinko, 1932: 202). Podejmując się analizy portretu Halikarnasyjczyka nakreślonego przez Plutarcha, musimy zwrócić uwagę, w ślad za Zofią Abramowiczówną, że w tradycyjnej łacińskiej wersji tytułu odpowiednik po-

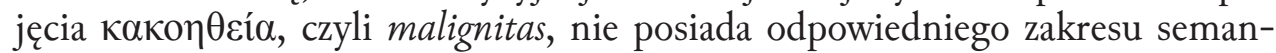
tycznego (Abramowiczówna, 1988: 260). Rzecz tu bowiem nie tylko o złośliwości Herodota, ale również o jego nieszczerości czy wręcz przewrotności. Stąd w przekładzie polskojęzycznym, dokonanym przez wspomnianą wybitną uczoną, tytuł ów brzmi $O$ złośliwości i przewrotności Herodota.

Herodot mija się z prawdą nie przez przypadek, czyli nieświadomie i bez złych intencji, lecz wiedziony perfidią. Dla Plutarcha jako moralisty dążność do prawdy była celem nadrzędnym, zwłaszcza gdy jest mowa o prawdzie historycznej. Należy jednocześnie zaznaczyć, że prawda miała dla niego wartość tak etyczną i dydaktyczną, jak i w pewnym sensie terapeutyczną. W interesującym nas traktacie wyraźnie widać, jak Plutarch z prawdą łączy duchowe pokrzepienie; postępowanie bez wątpienia właściwe dla tego, kto uważał się

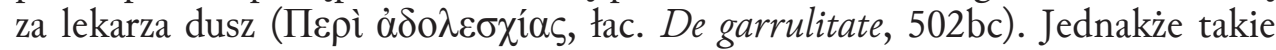
pojmowanie prawdy musiało, w mniejszym lub większym stopniu, skutkować relatywizmem. Etykieta kłamcy, którą jakże często w kolejnych stuleciach starożytni przyczepiali twórcy Dziejów, stała się dla Cheronejczyka bodźcem nie tylko do stworzenia traktatu dydaktycznego ku pokrzepieniu serc, ale również traktatu etyczno-psychologicznego o kłamstwie, a dokładniej o kłamaniu, czy, jak chce Guy Lachenaud, diatryby retorycznej (Lachenaud, 1981: 126). Z wielką wnikliwością, godną znawcy ludzkiej psychiki, ukazał Plutarch Herodotową technikę kłamania, ujawniając jednocześnie domniemane intencje historyka.

Halikarnasyjczyk posiadał, zdaniem naszego moralisty, skłonność do przejaskrawiania przedstawianych zdarzeń i ich bohaterów. Kosztem umiarkowania dążył do efekciarstwa (855b). Ze szczególnym uwielbieniem wyszukiwał postępki godne potępienia, które w rzeczywistości dla danego opowiadania nie miały żadnego znaczenia. Czynił tak, ponieważ w szkalowaniu znajdował przyjemność (855c). O ile Herodot o występkach swych bohaterów miał opowiadać skrupulatnie, o tyle ich zasługi pomija już milczeniem (855d). Oprócz milczenia inną, równie wysublimowaną, formą kłamstwa jest wybieranie tej wersji wydarzeń, na podstawie której odbiorca mógł poszczególne postaci ocenić wyłącznie krytycznie (855e-f).

W Dziejach nie brakuje, oczywiście, informacji o czynach świetnych i chwalebnych, ale i w tym przypadku do głosu dochodzi nieżyczliwość i złośliwość historyka. Uważa on bowiem, że w rzeczywistości sprawcy tychże czynów motywowani byli niskimi pobudkami - takimi jak strach lub zazdrość (856a-b). Wysublimowaną formą złośliwości Herodota są zapewnienia, iż nie wierzy w oszczerstwa, w które w istocie chce, aby wierzono (856c). Na koniec czyni go Plutarch obłudnikiem, który krytykę nierzadko poprzedza pochwała (856d). Pochwała miała mu zagwarantować wiarygodność. 
Cheronejczyk przypisał zatem twórcy Dziejów podstawowe formy kłamania, które niezmiennie stanowią przedmiot badań współczesnych psychologów i lingwistów. Wystarczy wspomnieć o tak zwanych maksymach konwersacyjnych Paula Grice'a, będących doskonałym narzędziem interpretacyjnym aktów mowy ${ }^{4}$.

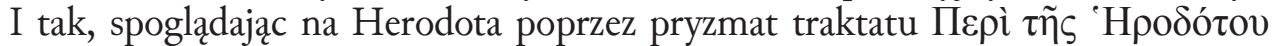

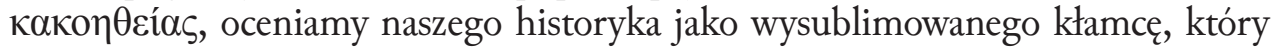
misternie łamie reguły kierujące prawidłowym przebiegiem międzyludzkiej komunikacji. Nie tylko nie przestrzega on maksymy jakości, czyli świadomie ucieka się do kłamstwa, ale również wątpliwości budzi w jego wykonaniu selekcja i dobór informacji. Nie dość, że często zbacza z wytyczonego nurtu tematycznego, to w dodatku zbyt wiele mówi. Tak oto odstępuje od maksymy ilości i relewancji.

Przyjrzyjmy się dokładniej kilku wybranym przykładom, jakimi Plutarch posłużył się, kreśląc wizerunek Herodota kłamcy, męża złośliwego i przewrotnego. Wrogi i krzywdzący stosunek twórcy Dziejów do Tebańczyków i Koryntian jest, jak wcześniej wspomniałam, przewodnim motywem omawianego traktatu. Przedstawienie Tebańczyków, którzy w Przesmyku Termopilskim walczyli u boku Spartiatów, jako zdrajców musiało wywołać oburzenie Plutarcha. Dowiadujemy się, że zginęli oni wraz z Leonidasem i trzystoma Spartiatami, ale ich śmierć, w przeciwieństwie do losu króla Sparty i jego żołnierzy, nie była aktem bohaterskim, lecz zasłużoną karą za zdradę. Szczególnie wymowne jest stwierdzenie Herodota, że Tebańczycy w Termopilach „zostali wbrew woli i niechętnie" ${ }^{5}$ (VII 222). Postawie owych przymusowych sprzymierzeńców przeciwstawił historyk z Halikarnasu postawę Leonidasa, który, decydując się na samodzielną walkę w Termopilach, miał oznajmić, że „jemu samemu nie wypada odejść" (VII 220, 2). Według Plutarcha twórca Dziejów żywił do Tebańczyków „osobistą złość i wrogośc”" ${ }^{\text {do }}$ tego stopnia, że nie zadbał nawet o prawdopodobieństwo swojej kłamliwej wersji (865b). Otóż wątpliwe jest, żeby Leonidas zdecydował się na zatrzymanie czterystu Tebańczyków uważanych za zdrajców u boku zaledwie trzystu Spartiatów (865c-d). Już tylko ich liczebna przewaga podważa prawdziwość Herodotowego przekazu.

Występując w roli adwokata Herodota, przede wszystkim przywołamy zawartą w Dziejach informację, że oprócz niechętnych czterystu Tebańczyków towarzyszyło

${ }^{4}$ Aby komunikacja międzyludzka przebiegała prawidłowo, należy przestrzegać określonych regut, nazwanych przez brytyjskiego filozofa języka Paula Grice'a maksymami konwersacyjnymi. I tak maksyma jakości polega na mówieniu tego, co można udowodnić i o czego prawdziwości jesteśmy przekonani; zgodnie zaś z maksymą ilości mówimy tyle, ile wymaga dana sytuacja konwersacyjna; maksymie relewancji (odpowiedniości) posłuszni jesteśmy wówczas, gdy mówimy na temat; z kolei maksyma sposobu nawołuje do klarownych, logicznych i jednoznacznych wypowiedzi (zob. Tabakowska, 2001: 219-235).

${ }^{5}$ Cytaty z Dziejów Herodota, o ile nie zaznaczono inaczej, przytaczane są w przekładzie Seweryna Hammera.

${ }^{6}$ Wszystkie cytaty ze Złośliwości i przewrotności Herodota podane zostały w przekładzie Zofii Abramowiczównej. 
Leonidasowi oddanych mu siedmiuset Tespijczyków (VII 202; 222)7. Przedstawienie Tebańczyków jako zakładników Leonidasa niektórzy uczeni poddali w wątpliwość. I tak Walter W. How i Joseph Wells w swym komentarzu do Herodota wyrazili opinię, że Plutarch w odniesieniu do omawianego zdarzenia zaatakował historyka słusznie (How \& Wells, 1957: 229). Również Abramowiczówna w przypisie do miejsca, w którym Plutarch prawi o sfałszowaniu przez Herodota roli, jaką Tebańczycy odegrali w Termopilach, wyraża opinię, że twórca Dziejów był, prawdopodobnie, wobec nich niesprawiedliwy (Abramowiczówna, 1988: 292).

Jeżeli nawet w naszym mniemaniu Herodot przedstawił owych czterystu Tebańczyków niezgodnie $\mathrm{z}$ prawdą, to $\mathrm{w}$ równym stopniu na naganę zasługuje w omawianym przypadku sam Plutarch. Otóż w kolejnym passusie swego traktatu (866a-b) nawiązał do najbardziej bohaterskiego, jego zdaniem, czynu Leonidasa, o którym w Dziejach zabrakło jakiejkolwiek wzmianki, czyli do brawurowej nocnej wyprawy Spartiatów do obozu „barbarzyńców” w celu zgładzenia króla Persów. Miała to być reakcja Lacedemończyków na wieść, że wróg okrąża wąwóz i odcina im drogę odwrotu. Taką wersję przebiegu walk w Termopilach, a dokładniej ich końcowego stadium zwieńczonego śmiercią niestrudzonych obrońców greckiej wolności, podał Diodor Sycylijski w swej Bibliotece (Bibliotheca X 10). Wobec tego rodzi się pytanie: dlaczego Cheronejczyk nie odwołał się do Diodora wówczas, gdy historykowi z Halikarnasu zarzucał kłamliwe i niegodne przedstawienie Tebańczyków stojących u boku Leonidasa? Sycylijczyk informuje bowiem, że w Termopilach walczyli ci Tebańczycy, którzy należeli do stronnictwa antyperskiego (Bibliotheca IX 4). Jest to najwyraźniej kwestia, którą moralista skwapliwie pomijał milczeniem i kreował własny jedynie prawdziwy wizerunek swych krajanów, dzielnie stawiających czoło Persom.

Halikarnasyjczyk, zdaniem Plutarcha, nie oszczędził też samego króla Sparty. Miał on odesłać sprzymierzeńców wiedziony rządzą sławy (865e). „To więc [sc. treść wyroczni] Leonidas rozważając i chcąc dla samych tylko Spartiatów zdobyć sławę, raczej odesłał sprzymierzeńców, niż żeby mieli, żywiąc odmienne poglądy, tak niesfornie precz odejść" - twierdzi Herodot (VII 220, 4). Ze słów historyka nie wynika jednak jasno, że Leonidas w swej decyzji kierował się egoizmem. Dlatego, jak można przypuszczać, Plutarch, cytując przywołany fragment z Dziejów, pominął jego część końcową i tym samym zniekształcił sens Herodotowych słów. Jest to kolejny przykład manipulowania przez naszego moralistę materiałem źródłowym ${ }^{8}$. Zapomniał on wspomnieć, że według

${ }^{7}$ Chociaż Plutarch, idąc za Herodotem, wymienił Tespijczyków jako tych, którzy pozostali z Lacedemończykami dobrowolnie, to jednak w swej argumentacji nie uwzględnit ich siły liczebnej. Na temat liczebności greckiej armii zgromadzonej w Termopilach zob. Murray, 2004: $381 \mathrm{n}$.

${ }^{8}$ Nie ma najmniejszych wątpliwości, że Plutarch wykorzystywał swój materiał źródłowy podług doraźnych potrzeb. Dowolne nim manipulowanie pozwalało mu stworzyć pełną wersję 
Herodota Leonidas odprawił z Termopil sprzymierzeńców, aby uniemożliwić im haniebną ucieczkę i tym samym oszczędzić wstydu. Uznanie zatem Leonidasa za męża $\theta \omega \mu \alpha \zeta o ́ \mu \varepsilon v o \varsigma ~ \mu \alpha ́ \lambda ı \sigma \tau \alpha$ (VII 204) nie wydaje się przejawem ani złośliwości, ani przewrotności historyka. Herodot ukazał go z głębokim szacunkiem i podziwem, tak jak należy przedstawiać bohatera heroicznego. Wyrazem zaś owego szacunku i podziwu było zachowanie przez „ojca historii” oficjalnego dystansu. Stąd postać Leonidasa otrzymała sylwetkę posągową. Obserwujemy go przede wszystkim jako dowódcę i dzielnego wojownika ${ }^{9}$.

Bohaterem zasłużonym dla Greków w czasie zmagań z Persami, wobec którego Herodot miał być ustosunkowany negatywnie, jest Temistokles. Według Plutarcha koronnym dowodem na antytemistoklesowe nastawienie Halikarnasyjczyka była historia o Mnesifilosie, który tuż po uchwaleniu przez greckich dowódców decyzji, że ich flota wyda bitwę nie pod Salaminą, lecz przed Istmem, udzielił ateńskiemu wodzowi rady, a właściwie ostrzeżenia przed konsekwencjami odwrotu spod Salaminy: „A zatem, jeżeli ci odbiją z okrętami od Salaminy, ty już za żadną ojczyznę nie będziesz na morzu walczył” (VIII 57, 2). W zaistniałej sytuacji powinnością ateńskiego wodza było nakłonienie głównodowodzącego helleńskiej floty, Eurybiadesa, do pozostania na pierwotnych pozycjach. Z Herodotowej relacji dowiadujemy się, że Temistokles słów Mnesifilosa wysłuchał bez komentarza, a następnie udał się do Eurybiadesa i wyłuszczył mu to wszystko, co od tamtego usłyszał, ,jako własną radę, dodając jeszcze wiele innych rzeczy" (VIII 58,2 ). Tak oto zarysowana postawa wybitnego Ateńczyka była dla Cheronejczyka jedną z pobudek do wysunięcia pod adresem twórcy Dziejów oskarżenia o niecne oszczerstwa. Stwierdzenie غ̇ $\mu \varepsilon v o \zeta$ musiało i musi, oczywiście, budzić pewne wątpliwości, ale nie świadczy jeszcze o złych intencjach ani Temistoklesa, ani tym bardziej samego Herodota. Sygnałem godnym uwagi, choć jednocześnie efemerycznym, jest pominięcie przytoczonego stwierdzenia w pochodzącym z XVI wieku rękopisie $\mathrm{M} \mathrm{Mu}-$ tinensis Estensis graecus 221. Ponadto w dalszej części cytatu przytoczonego

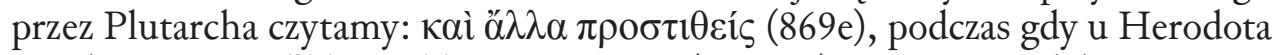

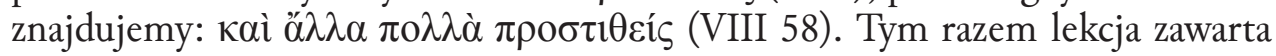
w omawianym traktacie zgadza się z tą, jaka została przyjęta w kodeksie M. Pominięty przez Cheronejczyka wyraz $\pi 0 \lambda \lambda \alpha$ ma tutaj istotne znaczenie. Wskazuje bowiem na rzeczywiste intencje zarówno Herodota, jak i jego bohatera. Temistokles został jedynie skutecznie zainspirowany radą Mnesifilosa, radą, której nie należy traktować jako misternie skonstruowanej mowy doradczo-perswazyjnej „skradzionej” przez ateńskiego wodza. Historyk przydzielił Mnesifilesowi

sekwencji zdarzeń z zachowaniem zamierzonego poziomu moralnego. Ważny jest tu, oczywiście, sposób pracy Cheronejczyka. Otóż jego excerpta z tekstu Dziejów nie zawsze musiały być dokładnymi cytatami, z pewnością nie brakowało wśród nich parafraz. Por. Pelling, 2007: 159; Hershbell, 1993: 149n.

${ }^{9}$ Szerzej o portrecie Leonidasa u Herodota zob. Marchewka, 2010: 213-215. 
wyłącznie rolę doradcy, a właściwie bardzo ważną w jego dziele funkcję tak zwanego ostrzegacza, czyli kogoś, kto nie posiada bezpośredniej siły sprawczej ${ }^{10}$. Jedynie mąż rozumny i zapobiegliwy — a za takiego, zdaniem twórcy Dziejów, Ateńczycy uważali Temistoklesa (VIII 110,1) - mógł zapobiec klęsce Grecji.

W odniesieniu do przywołanego przykładu wśród uczonych dziewiętnasto- i dwudziestowiecznych przeważa jednak pogląd w pewnej mierze zbliżony do oceny Plutarcha. I tak Ivo Bruns jest przekonany, że scena, w której Temistokles $\mathrm{w}$ rozmowie z Eurybiadesem z zapałem forsował myśl Mnesifilosa jako własną, z psychologicznego punktu widzenia jest nieprawdopodobna. Za wątpliwą uznał zdolność urzeczywistnienia zasłyszanego zamysłu z tak wielką determinacją i odwagą, skoro na wieść o upadku Aten greckich wodzów, w tym również Temistoklesa, ogarnęło przykre uczucie bezsilności i przerażenia (VIII 56). Owo nieprawdopodobieństwo w zachowaniu ateńskiego wodza miało być wynikiem sposobu pracy Halikarnasyjczyka — jego niewolniczego podejścia do tradycji (Bruns, 1896: 88n.). Chociaż Bruns wskazuje jedynie na niedoskonałość metody badawczej i literackiego warsztatu Herodota, to jest jasne, że jego zdaniem portret Temistoklesa został napiętnowany niechęcią historyka. Na niesprawiedliwe ukazanie w Dziejach bohatera spod Salaminy zwrócił uwagę Witkowski (Witkowski, 1925: 140). Na kreacji sylwetki Temistoklesa miały zaważyć Herodotowe sympatie względem Peryklesa; gdyż, jak wiadomo, twórca morskiej potęgi Aten był przeciwnikiem Alkmeonidów. Z całą pewnością Herodotowe przedstawienie Temistoklesa dalekie jest od panegiryku, ale też nie jest paszkwilem, jak chciałby tego Plutarch.

Dzieje bez wątpienia są przeniknięte sympatiami oraz antypatiami politycznymi Herodota. Ale niedorzeczne jest oskarżanie go o perfidne kłamanie. Ponadto zobrazowana w dziele Halikarnasyjczyka relacja pomiędzy Mnesifilosem a Temistoklesem nosi wyraźne znamiona rzeczywistych relacji tychże postaci ${ }^{11}$. Przeto krytyka Plutarcha nie jest tu w pełni uzasadniona, podobnie zreszta jak w wielu innych przypadkach. Nie ulega wątpliwości, że Temistokles został ukazany w Dziejach jako bohater zasługujący na uznanie.

Podobnie sylwetki Miltiadesa i Pauzaniasza, wybitnych obrońców greckiej wolności, w ujęciu Herodota nie są bez skazy (Marchewka, 2010: 128-133, 140-146).

${ }^{10}$ Ostrzegacz zajmuje w Dziejach oddzielne i zarazem bardzo ważne miejsce. Jego rola ogranicza się przeważnie do tak zwanej psychicznej interwencji, przy czym pojęcie to nie odnosi się tutaj do irracjonalnych zachowań bohaterów, wiedzionych boską wolą, lecz do ich decyzji i działań zracjonalizowanych. Oprócz Mnesifilosa wystarczy wspomnieć o doradcach-ostrzegaczach Krezusa, czyli o Solonie (Dzieje I 30-33), Sandanisie (I 71) oraz Biasie (Pittakosie) (I 27). Głos ostrzegacza jest zatem głosem rozsądku. Szerzej o roli ostrzegacza u Herodota zob. Bischoff, 1962: 302-319; por. też Marchewka, 2010: 45-48, 134.

${ }^{11}$ Postać Mnesifilosa pojawia się u Plutarcha również w Żywocie Temistoklesa (2,6), ale tym razem w roli wielbionego przez Temistoklesa mistrza, kontynuującego nauczanie Solona; czyli

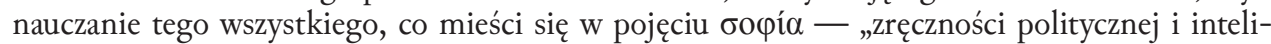
gencji praktycznej”. Zob. Bowen, 1992: 139n. 
Jednakże celem historyka nie było wyszukiwanie wad i przewinień greckich wodzów ani tym bardziej krytyczna ich ocena. Wręcz przeciwnie, sylwetki takich bohaterów, jak Miltiades, Temistokles czy Pauzaniasz, miały stanowić cenny wzorzec i naukę w czasach kryzysu helleńskich wartości i w obliczu bratobójczej wojny peloponeskiej, której pierwsze lata przypadły na schyłek życia Herodota. Owa dydaktyczna rola Dziejów najwyraźniej nie trafiła do przekonania Plutarcha. Do swych celów dydaktycznych potrzebował exemplum wzorcowego kłamcy, mistrza fałszowania przeszłości.

Przykładowo Cheronejczyk z ironią nawiązuje do strategicznego manewru Pauzaniasza nad Asoposem, manewru z założenia przecież rozsądnego i rokującego powodzenie. Polegat on na zamianie stanowisk wojsk ateńskich i lacedemońskich: Ateńczycy mieli walczyć z Persami, natomiast Lacedemończycy z Beotami i Tesalczykami (IX 46-47). Czynnikiem decydującym była, oczywiście, praktyka: Ateńczycy walczyli z Persami pod Maratonem. Plutarch epizod ów konkluduje w kpiącym tonie: śmieszne jest unikanie walki z nieprzyjacielem, jeśli się go nie zna (872b). Nie wspomniał tylko, że zaproponowany przez Pauzaniasza manewr strategiczny nie powiódł się, ponieważ Beoci, skoro tylko dostrzegli zmiany w ustawieniu wojsk helleńskich, natychmiast donieśli o nich Mardoniosowi. Dla autora traktatu był to kolejny przykład kłamstwa mającego na celu złośliwe spostponowanie Lacedemończyków.

Osadzona na kłamstwie złośliwość Herodota otarła się dodatkowo o bluź-

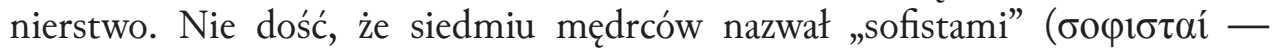
I 29, 1), to jednemu z nich, Solonowi, kazał znieważać bogów. W słynnym passusie Dziejów, poświęconym ludzkiemu szczęściu, ateński mędrzec zwraca uwagę Krezusowi, władcy przeświadczonemu o swym wyjątkowym szczęściu, na zależność ludzkiego losu od woli zmiennego i kapryśnego bóstwa (

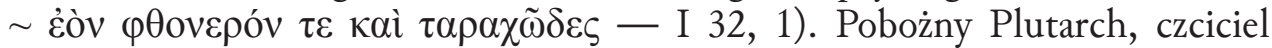
i kapłan Apollona, odebrał te słowa jako bluźnierstwo. Z drugiej jednak strony wydaje się, że tak wielki erudyta powinien wiedzieć, iż zarówno w czasach Solona, jak i Herodota, strach przed zawiścią bogów przenikał ludzką egzystencję na wskroś. Strach jest bowiem najbardziej pierwotnym uczuciem, jakie ludzie żywili wobec bogów. To właśnie on leży u podstaw greckiego fatalizmu, będącego przecież zasadniczą pożywką greckiej tragedii. Wątpliwości budzi także

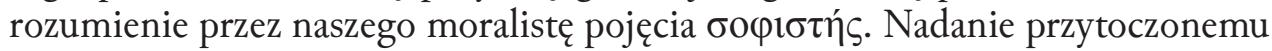
rzeczownikowi pejoratywnego znaczenia „sofista”, którego ani Herodot, ani jemu współcześni jeszcze nie znali, świadczy bądź o złej woli Plutarcha, bądź, co jest mało prawdopodobne, o jego niewiedzy ${ }^{12}$.

${ }^{12}$ Zdaniem Anthony'ego Bowena ów zarzut Plutarcha należy powiązać ze staraniami Platona, który od miana „sofista” usiłował oswobodzić Sokratesa. Natomiast w przypadku Herodota

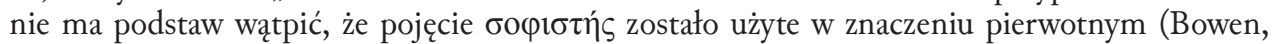
1992: 112). 
Musimy, oczywiście, pamiętać, że pięć wieków dzielących obu tych twórców to czas ciągłych zmian na wszystkich płaszczyznach życia Greków, czyli na płaszczyźnie politycznej, społecznej, ekonomicznej i kulturowej. Pomimo zatem greckich korzeni i wspólnoty języka, Halikarnasyjczyka i Cheronejczyka więcej różniło niż łączyło. I to do tego stopnia, że śmiało możemy tu mówić o dystansie kulturowym. Oczywista ewolucja języka greckiego oraz nieuniknione zmiany mentalne Hellenów spowodowały, że relacja pomiędzy Herodotem, półkrwi Karyjczykiem, a Plutarchem, który szczycił się rzymskim obywatelstwem, ma charakter międzykulturowy. Bariera pomiędzy pokoleniem „ojca historii” a pokoleniami późniejszymi, w tym i moralisty z Cheronei, wyrosła na gruncie wojen grecko-perskich. Mentalność Herodota ukształtowała się bowiem jeszcze w czasach, kiedy kultura Wschodu i Zachodu wzajemnie się przenikały symbioza ta miała, jak nam wiadomo, fundamentalne znaczenie $\mathrm{w}$ powstaniu greckiej kultury, podczas gdy Plutarch należał już do świata podzielonego na Wschód i Zachód (Murray, 2004: 388n.). Dychotomia ta była dla niego jedyną słuszną rzeczywistością, w której rządziły stereotypy „barbarzyńcy” i człowieka Zachodu, czyli świata grecko-rzymskiego.

Ostatecznie podstawowymi zarzutami, jakie Plutarch postawił twórcy Dziejów, są: fałszowanie faktów, oczernianie greckich bohaterów, nieszczere, a wręcz lekceważące przedstawienie wybitnych mędrców, polityków i strategów oraz wyraźne znamiona bezbożności. Należy jeszcze do tego dorzucić postponujące traktowanie kobiet $(856 \mathrm{e}-\mathrm{f})^{13}$, żeby stworzyć portret tępego i nieokrzesanego

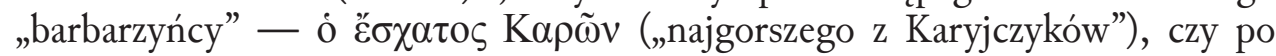
prostu, idąc za przekładem Abramowiczównej, „zakutego” Karyjczyka.

Wykreowany przez Plutarcha wizerunek „ojca historii” niektórzy nowożytni badacze uznali za dalece kontrowersyjny czy wręcz szokujący. Raziły ich dominujące $\mathrm{w}$ traktacie agresja i napastliwość autora; postawa ta pozostawała w sprzeczności z łagodnym usposobieniem moralisty. Stąd w wiekach XIX

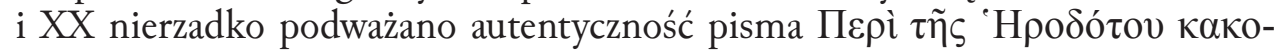
$\eta \theta \varepsilon i ́ a \varsigma^{14}$. Obecnie jego autorstwo nie stanowi już kwestii dyskusyjnej. Możemy się jedynie zastanawiać nad powodem tak bezwzględnego potraktowania Herodota. Najczęściej przywoływane są względy patriotyczne. Jednakże lokalny patriotyzm i romantyczne spojrzenie na przeszłość Hellady nie tłumaczą w pełni ataku Plutarcha na twórcę Dziejów. Zdaniem Helene Homeyer kluczowym aspektem jest tu tradycja literacka, w jakiej został osadzony ów traktat (Homeyer, 1967: 186). Powstał on, jak wiadomo, u progu rozkwitu

${ }^{13}$ Plutarch skrytykował wysunięty pod adresem Hellenów zarzut Herodota, że tylko głupcy mogli zbrojnie wyprawić się przeciwko Azji, a dokładniej Priamowi, z powodu porwanej niewiasty, bo przecież „gdyby same nie chciały, nie zostałyby uprowadzone” (Dzieje I 4, 2). Moralista nie wspomniał tylko, że ów pogląd jest własnością Persów, o czym historyk swego odbiorcę wyraźnie poinformował.

${ }^{14}$ Szerzej o autentyczności traktatu De Herodoti malignitate zob. Lachenaud, 1981: 114-117. 
nowej sofistyki. Dlatego tak materia, jak i krytyczna metoda, są dziedzictwem hellenizmu, po który Plutarch skwapliwie sięgat. W De Herodoti malignitate jawią się nam toposy wykorzystane już w hellenistycznej polemice historiograficznej. Ale, wbrew pozorom, moralista z Cheronei nie zamierzał polemizować z Herodotem z pozycji historyka. Trudno się tego spodziewać, skoro przy tworzeniu biografii zdecydowanie się odżegnał od roli historyka (Vita Alexandri Magni 1$)^{15}$.

Wpływ szkoły perypatetyckiej, który jaskrawo uwidocznił się w Żywotach równolegtych (biografia perypatetycka), oraz filozofii platońskiej zaowocował określonym sposobem pojmowania przez Plutarcha historii i prawdy historycznej. Pragnąc zatem jak najlepiej zilustrować charaktery swych bohaterów, ze szczególnym upodobaniem sięgał po anegdoty oraz apoftegmaty; naturalnie te, które przedstawiane postaci pozwalały ukazać w możliwie jak najkorzystniejszym świetle. Pomimo że szczycił się, iż w swych dociekaniach kieruje się obiektywizmem, to $\mathrm{w}$ rzeczywistości przyjęte przez niego kryterium oceny tego, co należy uznać za prawdę, a co za fałsz, pozostaje w sprzeczności z postawą człowieka bezstronnego. Intencje Plutarcha kłóciły się z ideą badawczego obiektywizmu. Prawdę chciał widzieć przede wszystkim w tym, co przynosiło moralny pożytek ${ }^{16}$.

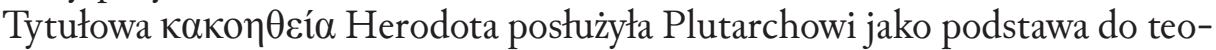
retycznych rozważań o kłamaniu. W oparciu o przykłady zaczerpnięte z Dziejów stworzył portret kłamcy o łagodnych i naiwnych rysach (tak jak styl Herodotowego dzieła), lecz już z odpychającym grymasem, zdradzającym niecne intencje. Stąd tak na początku, jak na końcu omawianego traktatu, ze szczególnym naciskiem odniósł się Cheronejczyk do uroku i prostoty stylu, dzięki któremu historyk z Halikarnasu zdołał zwieść odbiorcę. Przyobleczenie kłamliwych treści we wdzięk i harmonię było dla moralisty, któremu wiernie towarzyszyła myśl Platona (por. Rep. III ), szczytem obłudy. Herodot nie mógł służyć jako wzór dla młodzieży.

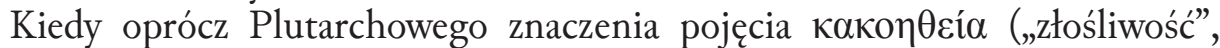
„przewrotność) uwzględnimy też jego znaczenie przyjęte w Państwie Platona

${ }^{15}$ Nieuzasadnione wydają się żale Homeyer, która zarzuciła Plutarchowi, że jako moralista zbyt wielką wagę przywiązywał do materii historycznej i że pod wpływem wcześniejszych osądów nie potrafil sprawiedliwie ocenić Herodota (Homeyer, 1967: 187).

${ }^{16}$ Plutarch jest doskonałym przykładem na to, jak dalece mogą odwieść od prawdy brak obiektywizmu i wiara $\mathrm{w}$ istnienie bezwzględnej prawdy, chociaż sam zdecydowanie przeciwstawia się relatywizmowi. Należy bowiem pamiętać, że Herodot i Plutarch pochodzili ze światów odmiennie nacechowanych intelektualnie. W świecie moralisty prawda definiowana jest pewnie i jednoznacznie, natomiast „ojciec historii” zdążył się zetknąć z nurtem myśli sofistycznej. Dlatego też Cheronejczykowi trudno było pojąć motywy historyka ukryte za pewnymi strategiami opowiadania, a które odbiorcy miały uświadomić trudność poznania i zrozumienia określonych wydarzeń. Otóż twórca Dziejów w odniesieniu do przeszłości częściej woli mówić o tym, co możliwe, a nie co pewne. Por. Baragwanath, 2008: 22-26, 34. 
(348d, 401a: „zły charakter”, wg przekł. W. Witwickiego) oraz jego definicję

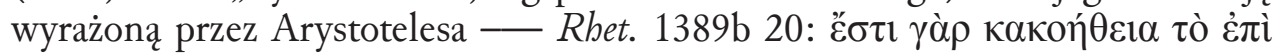

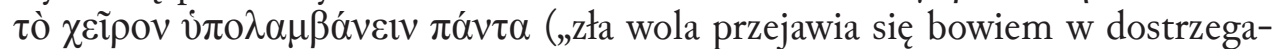
niu we wszystkim gorszych stron”, przeł. H. Podbielski), wówczas bez trudu

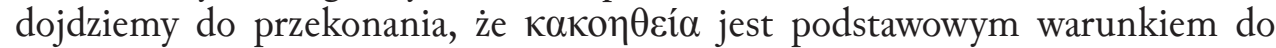
zaistnienia kłamstwa. Zły charakter, którego przejawem jest niesprawiedliwość, oraz złą wolę, czyli uwzględniane tylko tego, co gorsze, Cheronejczyk z wielką wnikliwością doprecyzował i sprowadził do poziomu hipokryzji. Warunkiem prawdy jest bowiem szczerość, czyli przekazywanie informacji opartych na wiedzy nadawcy. Na pytanie zatem, do jakiego stopnia Herodot mógł być tendencyjny i kłamać świadomie, a do jakiego pozostawał w stanie fałszywej świadomości, czyli po prostu niewiedzy, Plutarch dał nam odpowiedź jednoznaczną, druzgoczącą twórcę Dziejów.

Jeżeli pismo De Herodoti malignitate miało pełnić z góry określone cele dydaktyczne, to automatycznie rodzi się pytanie, czy nakreślony w nim wizerunek Herodota odzwierciedla rzeczywisty do niego stosunek Cheronejczyka. Czy ów bezwzględny atak na twórcę Dziejów był przejawem złośliwości Plutarcha? Przecież nigdzie w pozostałej swej twórczości nie zanegował on wartości dzieła Halikarnasyjczyka tak zdecydowanie, jak uczynił to w interesującym nas traktacie. I tak na brak konsekwencji naszego moralisty w ocenie Herodota zwrócił uwagę Christopher Pelling (Pelling, 2007: 162). Z wielką niechęcią względem historyka, wyrażoną w $O$ ztośliwości i przewrotności Herodota, kontrastuje bardzo pozytywne względem niego nastawienie w piśmie Nauka Epikura (nawet) nie umożliwia przyjemnego życia (Non posse suaviter vivi secundum Epicurum). Otóż stwierdza w nim Plutarch:

[...] kiedy badanie i opowieść nie ma w sobie nic szkodliwego ani przykrego, a do opisu spraw wielkich i pięknych doda wysłowienie pełne siły i uroku, jak Herodota Dzieje Hellady albo Ksenofonta Dzieje Persji [...], to nie dość, że przyjemność z tego jest wielka i różnorodna, lecz także czysta i nie wywołująca skruchy (Plutarch Non posse 1093b-c) (przeł. Z. Abramowiczówna).

\section{ZASADY PRZYWOŁYWANIA TEKSTÓW ŹRÓDŁOWYCH}

Odwołania do tekstów Plutarcha wedle podziału stosowanego w krytycznych wydaniach odpowiednio Moraliów (paginacja Oleariusa) i Żywotów równoległych (tytuł biografii, rozdział, paragraf). W odwołaniach do Platona tradycyjna, wykorzystywana w edycjach krytycznych paginacja Stephanusa; w odwołaniach do Arystotelesa - paginacja Bekkera. Referencje do tekstów historyków (Herodot, Diodor Sycylijski) zgodnie z podziałem rozdziałów ogólnie stosowanym w wydaniach krytycznych (księga, rozdział). Wszystkie teksty greckie (a także odniesienia) wedle bazy danych Thesaurus Linguae Graecae ${ }^{\circledR}$ Digital Library. (Ed. M. C. Pantelia). Irvine: University of California. Dostęp: http://www.tlg.uci.edu (28.12.2017). 


\section{BIBLIOGRAFIA}

Abramowiczówna, Z. (Przekł., wstęp i przypisy). (1988). Plutarch, Moralia (Wybór) (t. 2). Warszawa: Wydawnictwo Naukowe PWN.

Baragwanath, E. (2008). Motivation and narrative in Herodotus. Oxford: Oxford University Press.

Bischoff, H. (1962). Der Warner bei Herodot (s. 302-319). W: W. Marg (Red.). Herodot. Eine Auswabl aus der neueren Forschung. Darmstadt: Wissenschaftliche Buchgesellschaft.

Bowen, A. J. (Przekt. wstęp i koment). (1992). Plutarch, The malice of Herodotus (de malignitate Herodoti). Warminster: Aris \& Phillips.

Bruns, I. (1896). Das literarische Porträt der Griechen. Berlin: Hertz.

Fornara, Ch. W. (1971). Evidence for the date of Herodotus' publication. Journal of Hellenic Studies, 91, 25-34.

Hershbell, J. P. (1993). Plutarch and Herodotus - the beetle in the rose. Rheinisches Museum, 136, 143-163.

Homeyer, H. (1967). Zu Plutarchs De malignitate Herodoti. Klio, 49, 181-187.

Hornblower, S. (2006). Herodotus' influence in antiquity (s. 306-318). W: C. Dewald \& J. Marincola (Red.). The Cambridge companion to Herodotus. Cambridge: Cambridge University Press.

How, W. W. \& Wells, J. (1957). A Commentary on Herodotus (t. 2). Oxford: Oxford University Press.

Lachenaud, G. (1981). Notice (t. 12/1; s. 107-136). W: M. Cuvigny \& G. Lachenaud (Wyd.). Plutarque: Oeuvres morales. Paris: Les Belles Lettres.

Marchewka, A. (2010). Stowo i gest. Herodotowa sztuka portretowania. Gdańsk: Wydawnictwo Uniwersytetu Gdańskiego.

Murray, O. (2004). Narodziny Grecji. (Przeł. A. Twardecki). Warszawa: Prószyński i S-ka.

Pelling, Ch. (2007). De Malignitate Plutarchi: Plutarch, Herodotus, and the Persian wars (s. 145-164). W: E. Bridges, E. Hall, \& P. J. Rhodes (Red.). Cultural responses to the Persian wars. Antiquity to the third millennium. Oxford: Oxford University Press.

Sinko, T. (1932). Literatura grecka (t. 1/2). Kraków: Polska Akademja Umiejętności.

Tabakowska, E. (Red.). (2001). Kognitywne podstawy jezyka i jezykoznawstwa. Kraków: Universitas.

West, S. R. (1999). Sophocles' Antigone and Herodotus Book Three (s. 109-136). W: J. Griffin (Red.). Sophocles revisited: Essays presented to Sir Hugh Lloyd-Jones. Oxford: Oxford University Press.

Witkowski, S. (1925). Historiografja grecka i nauki pokrewne (t. 1). Kraków: Polska Akademia Umiejętności.

Ziegler, K. (1951). Plutarchos von Chaironea. Paulys Realencyclopädie der classischen Altertumswissenschaft, 21(1), 639-962. 